\title{
Symposium on Child Development and Parental Investment: Introduction*
}

\author{
Marco Francesconi \\ James J. Heckman \\ University of Essex \\ University of Chicago \\ and IFS \\ Center for the Economics \\ of Human Development \\ American Bar Foundation \\ and IFS
}

December 8, 2015

\footnotetext{
*We thank Sneha Elango for comments on this introduction. This research was supported in part by: the Pritzker Children's Initiative; the Buffett Early Childhood Fund; NIH grants NICHD R37HD065072, NICHD R01HD54702, and NIA R24AG048081; an anonymous funder; Successful Pathways from School to Work, an initiative of the University of Chicago's Committee on Education and funded by the Hymen Milgrom Supporting Organization; the Human Capital and Economic Opportunity Global Working Group, an initiative of the Center for the Economics of Human Development and funded by the Institute for New Economic Thinking; and the American Bar Foundation. The views expressed in this paper are solely those of the authors and do not necessarily represent those of the funders or the official views of the National Institutes of Health.
} 


\begin{abstract}
This paper introduces the EJ Symposium on Child Development by reviewing the literature and placing the contributions of the papers in the Symposium in the context of a vibrant literature.
\end{abstract}

Keywords: child development, education, dynamic complementarity

JEL codes: H43, I21, I24, J13, J24

$\begin{array}{ll}\text { James Heckman } & \text { Marco Francesconi } \\ \text { Department of Economics } & \text { Department of Economics } \\ \text { University of Chicago } & \text { University of Essex and IFS } \\ 1126 \text { East 59th Street } & \text { Colchester CO4 3SQ } \\ \text { Chicago, IL 60637 } & \text { United Kingdom } \\ \text { Phone: 773-702-0634 } & \text { Phone: 44(0)1206-872765 } \\ \text { Email: jjh@uchicago.edu } & \text { Email: mfranc@essex.ac.uk }\end{array}$




\section{Introduction}

A growing body of research in economics, epidemiology, and developmental psychology establishes the importance of attributes shaped in childhood in determining adult outcomes. At least $50 \%$ of the variability of lifetime earnings across persons results from attributes of persons determined by age $18 .{ }^{1}$ Childhood is the province of the family and the environments in which families are situated. Any investigation of how conditions in childhood affect life outcomes is a study of family influence and the influence of family environments.

The papers in this collection contribute to a vibrant recent literature that investigates the determinants and consequences of parental actions and childhood environments on child outcomes. That literature is based on multi-generation models with distinct developmental periods of childhood and adulthood and multiple skills. It demonstrates the value of a variety skills, not just IQ or skills measured by achievement tests. An approach based on the dynamic evolution of skills unifies the literature on family economics with the intervention literature and the literature on schooling.

This approach emphasizes the dynamics of skill formation. Central to the literature are the concepts of complementarity, dynamic complementarity, the multiplicity of skills, and critical and sensitive periods in the life of a child for different skills. These concepts account for a variety of empirical regularities that describe the process of human development.

Family environments during the early years, and especially parenting, are major determinants of human development because they shape the foundation for lifetime skill development formed before children enter formal schooling. Through dynamic complementarity, they enhance the productivity of downstream investments. The literature establishes conditions under which it is socially productive to invest in the early years of disadvantaged children. These conditions are supported by evidence reported in the literature. Later-stage remedial interventions for cognitive skills are generally less effective. Interventions aimed at disadvantaged adolescents can be effective if they target the enhancement of noncognitive skills and provide valuable

\footnotetext{
${ }^{1}$ See Cunha et al. (2005); Huggett et al. (2011); Keane and Wolpin (1997).
} 
information that helps adolescents utilize their skill-base and make wise choices.

Just as it is imprecise to proxy human capital by scores on IQ or achievement tests, it is inadequate to measure parental investment only in terms of financial expenditures on the child. This practice may contribute to the current emphasis in the literature on credit constraints as a major source of achievement gaps. The importance of the timing of receipt of income and the role of credit constraints in shaping child development is a hotly debated issue in the field. It receives some attention in this issue in the paper by Carneiro and Ginja. Their work supports the contention that the importance of financial resources in shaping child outcomes has been exaggerated in the recent literature compared to the importance of parenting and mentoring. Untargeted cash transfers are unlikely to be effective tools for promoting child skills (see Cunha, 2007, Caucutt and Lochner, 2012, and Del Boca, Flinn and Wiswall in this issue).

The recent literature uses multiple empirical methodologies: observational studies of family influence including both reduced form treatment effect models, structural models, and social experiments. All methodological approaches are represented in this issue.

Heckman and Mosso (2014) summarize the recent economic literature on human development through adolescence and early adulthood. The early literature on family influence and the determinants of social mobility pioneered by Becker and Tomes $(1979,1986)$ developed multiple-generation models with one period of childhood, one period of adulthood, one-child families (with no fertility choices), and a single parent. These models are precursors to the modern literature.

Becker and Tomes do not analyze marital sorting and family formation decisions. Parental engagement with the child is in the form of investments in educational goods analogous to firm investments in capital equipment. In the early literature on child development, the role of the child is passive and parents are perfectly informed. Parental time investments in children are mentioned, but ignored in the early empirical analyses for want of data. (The Del Bono et al. paper contributes to this literature by introducing parental time as an input. See also Del Boca et al., 2014 and their paper in this issue.) 
In the early literature, investments at any stage of childhood are assumed to be equally effective in producing adult skills. The output of child quality from family investment is a scalar measure of cognition (IQ or an achievement test) or "human capital." These concepts are often used interchangeably in the early literature.

Recent research in the economics of human development focuses on skills and the technology of skill formation. It establishes the importance of accounting for: (1) multiple distinct developmental periods in the life cycle of childhood and, in particular, the existence of critical and sensitive periods of childhood in the formation of skills; (2) multiple skills for both parents and children that extend traditional notions about the skills required for success in life; and (3) multiple forms of investment, including parenting and schooling. Some of the most exciting recent research models parent-child/mentor-child, and parent-teacher-child relationships as interactive systems, involving attachment and scaffolding ${ }^{2}$ as important determinants of child development. The recent literature also takes a more nuanced view of child investment and accounts for parental time and lack of parental knowledge about the capacities of children and effective parenting practices. ${ }^{3}$ It creates and implements an econometric framework that unifies the study of family influence and external interventions on child outcomes. ${ }^{4}$

Many interpret the well-established empirical relationship between family income and child achievement as evidence of market failures including credit constraints. Although it is conceptually attractive to do so, and amenable to analysis using standard methods, the empirical evidence that credit constraints substantially impede child skill formation is not especially strong. ${ }^{5}$ Family income proxies many aspects of the family environment-parental education, ability, altruism, personality, and peers. The recent empirical literature suggests that unrestricted income transfers are a weak reed for promoting child skills and the papers assembled here support

\footnotetext{
${ }^{2}$ Scaffolding is an adaptive interactive strategy that recognizes the current capacities of the child (trainee) and guides him or her to further learning without frustrating the child. Activities are tailored to the individual child's ability so they are neither too hard or too easy in order to keep in the "zone of proximal development," which is the level of difficulty at which the child can learn the most. See Heckman and Mosso (2014), Sroufe et al. (2005), Hotz and Pantano (2013) and García and Heckman (2015).

${ }^{3}$ See Cunha et al. (2013).

${ }^{4}$ See Cunha and Heckman (2009) and Cunha et al. (2010).

${ }^{5}$ See the evidence in Heckman and Mosso (2014).
} 
this proposition (see especially the Del Boca et al. paper). Before turning to a discussion of the individual papers, it is useful to review the findings of the recent literature.

\section{Some Facts about Skills Over the Life Cycle Drawn from the Recent Literature}

Skills are multiple in nature and encompass cognition and personality, as well as health. The recent empirical literature establishes some key features of human development and its measurement (see Cunha et al., 2006, Almond and Currie, 2011 and Heckman and Mosso, 2014 for extensive discussions of the evidence.)

\section{$1.1 \quad$ Skills}

Multiple skills determine a wide variety of life outcomes. Considerable evidence shows that cognitive and noncognitive (socioemotional) skills influence labor market outcomes, the likelihood of marrying and divorcing, the likelihood of receiving welfare, voting, and health. Comprehensive surveys are presented in Borghans et al. (2008), Almlund et al. (2011), Heckman and Kautz (2014), and Kautz et al. (2014). Heckman et al. (2015a,b) present fresh evidence on their importance.

Gaps in Skills Gaps in skills across socioeconomic groups open up at early ages for both cognitive and noncognitive skills. Carneiro and Heckman (2003), Cunha et al. (2006), and Cunha and Heckman (2007) present evidence of early divergence in cognitive and noncognitive skills across socioeconomic classes before schooling begins. Heckman and Mosso (2014) cite a variety of studies documenting this fact. Many studies show near-parallelism in measures of these skills during the school years across children of parents from different socioeconomic backgrounds, even though schooling quality is very unequal across these groups.

Genes The early emergence of skill gaps might be interpreted as the manifestation of genetics: Smart parents earn more, achieve more, and have smarter children. 
There is, however, a strong body of experimental evidence on the powerful role of parenting and parenting supplements, including mentors and teachers, in shaping skills. ${ }^{6}$

Genes are important, but skills are not solely genetically determined. The role of heritability is exaggerated in many studies and in popular discussions (see, e.g., Harris, 2006). Environments can trigger the expression of some genes, and can suppress or enhance gene expression in other cases (Moffitt, 2005). Nisbett et al. (2012), Tucker-Drob et al. (2009), and Turkheimer et al. (2003) show that estimated heritabilities are larger in families of higher socioeconomic status. Genes need sufficiently rich environments to fully express themselves. There is mounting evidence that gene expression is itself mediated by environments (see the evidence cited in Heckman and Mosso, 2014). Epigenetics ${ }^{7}$ informs us that environmental influences are partly heritable. ${ }^{8}$

\subsection{Critical and Sensitive Periods in the Technology of Skill Formation}

There is compelling evidence for critical and sensitive periods in the development of a child. The production of skills shows differential malleability at different stages of the life cycle (see Thompson and Nelson, 2001, Knudsen et al., 2006, and the body of evidence summarized in Cunha et al., 2006 and Heckman and Mosso, 2014). For example, IQ is rank stable after age 10, whereas personality skills are malleable from early childhood through adolescence and into early adulthood. ${ }^{9}$ A substantial body of evidence from numerous disciplines shows the persistence of early life disadvantage in shaping later life outcomes. Early life environments are important for explaining a variety of diverse outcomes, such as crime, health, education, occupation, social engagement, trust, and voting. Readers are referred to Cunha et al.

\footnotetext{
${ }^{6}$ There is also evidence that, on average, $50 \%$ of all traits are heritable. However, average differences in general cognitive ability across groups are small compared with individual differences within groups (Plomin, 1999).

${ }^{7}$ The study of heritability not related with DNA sequencing.

${ }^{8}$ See Cole et al. (2012); Gluckman and Hanson (2005, 2006); Jablonka and Raz (2009); Kuzawa and Quinn (2009); Rutter (2006).

${ }^{9}$ These results are anticipated in an early study by Bloom (1964).
} 
(2006); Heckman and Mosso (2014) and Almond and Currie (2011) for reviews of numerous studies on the importance of prenatal and early childhood environments on adolescent and adult health ${ }^{10}$ and socioeconomic outcomes.

\subsection{Family Investments}

Gaps in skills by age across different socioeconomic groups have counterparts in gaps in family investments and environments. Hart and Risley (1995), Fernald et al. (2013), and many other scholars show how children from disadvantaged environments are exposed to a substantially less rich vocabulary than children from more advantaged families. At age three, children from professional families speak $50 \%$ more words than children from working-class families and more than twice as many compared to children from welfare families (see Hart and Risley, 1995). There is substantial research literature summarized in Cunha et al. (2006), Lareau (2011), Kalil (2013), and Moon (2014) showing that disadvantaged children have compromised early environments as measured on a variety of dimensions. ${ }^{11}$ Recent evidence from Cunha et al. (2013) documents the lack of parenting knowledge among disadvantaged parents. Parenting styles are important determinants of early child development (Fiorini and Keane, 2014; Del Bono et al. in this issue). Parenting styles in disadvantaged families are found to be much less supportive of learning and encouraging child exploration (see Hart and Risley, 1995; Kalil, 2013; Lareau, 2011).

\subsection{Resilience and Targeted Investment}

Although early life conditions are important, there is considerable evidence of resilience and subsequent partial recovery. To our knowledge, there is no substantial body of evidence on full recovery from initial disadvantage. The most effective adolescent interventions target the formation of personality (socioemotional and character skills) through mentoring and guidance, and also provide information. This

\footnotetext{
${ }^{10}$ For example, Barker (1990) and Hales and Barker (1992) propose a "thrifty phenotype" hypothesis, now widely accepted, that reduced fetal growth is associated with a number of chronic conditions later in life (Gluckman and Hanson, 2005, 2006).

${ }^{11}$ See Heckman and Mosso (2014) for additional evidence.
} 
evidence is consistent with the greater malleability of personality and character skills into adolescence and young adulthood compared to cognitive skills, and especially IQ, which becomes rank stable before puberty. The body of evidence to date shows that, as currently implemented, many later life remediation efforts are not effective in improving the cognitive skills and life outcomes of children from disadvantaged environments. ${ }^{12}$ As a general rule, the economic returns to these programs are smaller compared to those policies aimed at closing gaps earlier (see Cunha et al., 2006; Heckman and Kautz, 2014; Heckman et al., 1999). However, workplace-based adolescent intervention programs and apprenticeship programs with mentoring, surrogate parenting, and guidance show promising results. They foster important character skills, such as increasing self-confidence, ability to work in teams, autonomy, and discipline, which are often lacking in disadvantaged youth. In recent programs with only short-term follow-ups, mentoring programs in schools that provide students with information that improves their use of the stock of existing skills have also been shown to be effective (see, e.g., Alan and Ertac, 2014; Bettinger et al., 2012; Carrell and Sacerdote, 2013; Cook et al., 2014).

\subsection{Parent-child/Mentor-child Interactions Play Key Roles in Promoting Child Learning}

A recurrent finding from the family influence and intervention literatures is the crucial role of child-parent/child-mentor relationships that "scaffold" the child (i.e., track the child closely, encourage the child to take feasible next steps forward in his or her "proximal zone of development," and do not bore or discourage the child). Successful interventions across the life cycle share this feature. ${ }^{13}$

\subsection{High Returns to Early Investment}

Despite the generally low returns to interventions targeted toward the cognitive skills of disadvantaged adolescents, the empirical literature shows high economic returns

\footnotetext{
${ }^{12}$ See the evidence in Heckman and Mosso, 2014. Rutter (2010) show that Romanian orphans reared in severely disadvantaged environments but adopted out to more advantaged environments partially recover, with recovery being the greatest among those adopted out at the earliest ages.

${ }^{13}$ See Schore (1994), Sroufe et al. (2005), Heckman and Mosso (2014) and García and Heckman (2015).
} 
for investments in young disadvantaged children. There is compelling evidence that high-quality interventions targeted to the early years are effective in promoting skills (Kautz et al., 2014). This evidence is explained by the concept of dynamic complementarity introduced in Cunha and Heckman (2007, 2009) and discussed extensively in Heckman and Mosso (2014). Recent interventions with short-term follow-ups appear to show remarkable effects on achievement test scores (See Cook et al., 2014). These findings may appear to contradict the evidence on the rank stability of IQ before the onset of puberty. However, as noted by Borghans et al. (2008), Almlund et al. (2011), Heckman and Kautz (2012, 2014), and Borghans et al. (2011b), the scores on achievement tests are heavily weighted by personality skills. Achievement tests are designed to measure "general knowledge" — acquired skills. This evidence is consistent with the evidence from the Perry Preschool Program that showed boosts in achievement test scores without raising IQ. Perry boosted noncognitive skills.

\section{Skills, the Technology of Skill Formation, and the Essential Ingredients of a Life-Cycle} Model of Human Development

The recent literature shows that skills, the technology of producing skills, and parental preferences and constraints play key roles in explaining the dynamics of family influence. We briefly review this literature in order to place the results of this Symposium in context.

\section{$2.1 \quad$ Skills}

We represent the vector of skills at age $t$ over lifetime $T$ by $\boldsymbol{\theta}_{\boldsymbol{t}}$. We decompose $\boldsymbol{\theta}_{\boldsymbol{t}}$ into three subvectors according to recent practice in the economics of human development: 


$$
\boldsymbol{\theta}_{\boldsymbol{t}}=\left(\boldsymbol{\theta}_{C, \boldsymbol{t}}, \boldsymbol{\theta}_{\boldsymbol{N}, \boldsymbol{t}}, \boldsymbol{\theta}_{\boldsymbol{H}, \boldsymbol{t}}\right), \quad t=1, \ldots, T
$$

where $\boldsymbol{\theta}_{\boldsymbol{C}, \boldsymbol{t}}$ is a vector of cognitive skills (e.g. IQ) at age $t, \boldsymbol{\theta}_{\boldsymbol{N}, \boldsymbol{t}}$ is a vector of noncognitive skills (e.g. patience, self-control, temperament, risk aversion, discipline, and neuroticism) at age $t$, and $\boldsymbol{\theta}_{\boldsymbol{H}, \boldsymbol{t}}$ is a vector of health stocks for mental and physical health at age $t$.

Skills evolve with age and experience $t$. The dimensionality of $\boldsymbol{\theta}_{\boldsymbol{t}}$ may also change with $t$. As people mature, they acquire new skills and sometimes shed old skills. Skills serve to determine: (a) resource constraints, (b) agent information sets, and (c) expectations.

A key idea in the recent literature is that a core low-dimensional set of skills joined with incentives and constraints generates a variety of diverse outcomes, although both the skills and their relationship with outcomes may change with the stage of the life cycle. An active body of research investigates the role of skills in producing outcomes (see Almlund et al., 2011; Borghans et al., 2008; Bowles et al., 2001; Dohmen et al., 2010). In general, different outcomes are differentially affected by the components of skill vector $\boldsymbol{\theta}_{\boldsymbol{t}}$ and the weights vary over the life cycle. Schooling completion, for example, depends more strongly on cognitive abilities, whereas earnings are equally affected by cognitive skills and noncognitive skills such as conscientiousness. ${ }^{14}$ Heckman et al. (2013) and García (2014) show that HS graduation/college attendance depend more on cognitive skill, but employment at age 30 is mediated far more by non-cognitive skills. ${ }^{15}$ Scores on achievement tests depend on both cognitive and non-cognitive skills (Borghans et al., 2011a). ${ }^{16}$ Evidence that achievement tests predict outcomes better than measures of personality or IQ alone miss the point that achievement tests capture both. ${ }^{17}$ As the mapping of skills to outputs differs among tasks, people with different levels of skills will also

\footnotetext{
${ }^{14}$ See Almlund et al. (2011) for the definition of the Big Five attributes used in personality psychology. They have been called the "latitude and longitude of personality."

${ }^{15}$ See Elango et al., 2015, Figure 6.

${ }^{16}$ See Borghans et al. (2008) and Heckman and Kautz $(2012,2014)$. This point is confused in a literature that equates cognition with scores on achievement tests.

${ }^{17}$ For a recent example of this sort of confusion, see Duckworth et al. (2012).
} 
have comparative advantages in performing different tasks. ${ }^{18}$

\subsection{Technology}

An important ingredient in the recent literature on the economics of human development is the technology of skill formation (Cunha, 2007; Cunha and Heckman, 2007), where the vector $\boldsymbol{\theta}_{\boldsymbol{t}}$ evolves according to a law of motion affected by investments broadly defined as actions specifically taken to promote learning, and parental skills (environmental variables):

$$
\theta_{t+1}=f^{(t)}(\underbrace{\theta_{t}}_{\begin{array}{c}
\text { self productivity } \\
\text { and cross effects }
\end{array}}, \underbrace{\theta_{\begin{array}{c}
\text { parental } \\
\text { skills }
\end{array}}^{\theta_{P, t}}}_{\begin{array}{c}
\text { investments } \\
I_{t}
\end{array}}) .
$$

$f^{(t)}$ is assumed to be twice continuously differentiable, increasing in all arguments and concave in $\boldsymbol{I}_{\boldsymbol{t}}$. Investment includes schooling, parenting and parental support of children in schools. As noted above, the dimension of $\boldsymbol{\theta}_{\boldsymbol{t}}$ and $\boldsymbol{f}^{(\boldsymbol{t})}$ likely increases with the stage of the life cycle $t$, as does the dimension of $\boldsymbol{I}_{\boldsymbol{t}}$. New skills emerge along with new investment strategies. The technology is stage-specific, allowing for critical and sensitive periods in the formation of skills and the effectiveness of investment. ${ }^{19}$ This technology accommodates the family formation of child preferences, as in Becker and Mulligan (1997), Becker et al. (2012), Bisin and Verdier (2001), and Doepke and Zilibotti (2012).

The first term in equation (2) captures two distinct ideas: (a) that investments in skills do not fully depreciate within a period and (b) that stocks of skills can act synergistically (cross partials may be positive). For example, higher levels of noncognitive skills promote higher levels of cognitive skills, as shown in the econometric studies of Cunha and Heckman (2008) and Cunha et al. (2010).

A crucial concept emphasized in the recent literature is complementarity between skills and investments at later stages $\left(t>t^{*}\right)$ of childhood:

\footnotetext{
${ }^{18}$ One version of this is the Roy model of occupational choice. See, e.g., Heckman and Sedlacek (1985).

${ }^{19}$ The technology is a counterpart to the models of adult investment associated with Ben-Porath (1967) and its extensions (see, e.g., Browning et al., 1999 and Rubinstein and Weiss, 2006). It is more general than the Ben-Porath model and its extensions, because it allows for multiple skill outputs $\left(\boldsymbol{\theta}_{\boldsymbol{t}}\right)$ and multiple inputs $\left(\boldsymbol{I}_{\boldsymbol{t}}\right)$, where inputs at one stage of the life cycle can be qualitatively different from investments at other stages of the life cycle. Cunha et al. (2006) compare technology (2) with the Ben-Porath model.
} 


$$
\frac{\partial^{2} \boldsymbol{\theta}_{\boldsymbol{t + 1}}}{\partial \boldsymbol{\theta}_{\boldsymbol{t}} \partial \boldsymbol{I}_{\boldsymbol{t}}^{\prime}}>0, \quad t>t^{*}{ }^{20}
$$

The recent empirical literature is consistent with the notion that investments and endowments are direct substitutes (or at least weak complements) at early ages,

$$
\frac{\partial^{2} \boldsymbol{\theta}_{\boldsymbol{t}+\mathbf{1}}}{\partial \boldsymbol{\theta}_{\boldsymbol{t}} \partial \boldsymbol{I}_{\boldsymbol{t}}^{\prime}} \leq 0, \quad t<t^{*},\left(\text { or } \epsilon>\frac{\partial^{2} \boldsymbol{\theta}_{\boldsymbol{t}+\mathbf{1}}}{\partial \boldsymbol{\theta}_{\boldsymbol{t}} \partial \boldsymbol{I}_{\boldsymbol{t}}^{\prime}}>0, \text { for "small" } \epsilon\right)
$$

but that complementarity increases with age:

$$
\frac{\partial^{2} \boldsymbol{\theta}_{\boldsymbol{t}+\mathbf{1}}}{\partial \boldsymbol{\theta}_{\boldsymbol{t}} \partial \boldsymbol{I}_{\boldsymbol{t}}^{\prime}} \uparrow t .^{21}
$$

Growing complementarity with the stage of the life cycle captures two key ideas. The first is that investments in adolescents and adults with higher levels of skill $\boldsymbol{\theta}_{\boldsymbol{t}}$ tend to be more productive. This is a force for disequalization of investment across ability groups if investment decisions are made solely on the basis of economic efficiency. Investment in the more able (those with higher $\boldsymbol{\theta}_{\boldsymbol{t}}$ ) is more efficient. It is consistent with evidence reported by Cameron and Heckman (2001), Cunha et al. (2006), Carneiro et al. (2013), and Eisenhauer et al. (2015) that returns to college are higher for more able and motivated students.

The second idea is that complementarity tends to increase over the life cycle. This implies that compensatory investments tend to be less effective the later the stage in the life cycle. This feature is consistent with a large body of evidence reviewed in Cunha et al. (2006) and Heckman and Mosso (2014) that shows that later life remediation is generally less effective than early life prevention and investment (Cunha et al., 2006; Heckman and Kautz, 2014; Knudsen et al., 2006; Sroufe et al.,

\footnotetext{
${ }^{20}$ There are other notions of complementarity. For a discussion with reference to the technology of skill formation, see Cunha et al. (2006).

${ }^{21}$ See Cunha (2007), Cunha and Heckman (2008), and Cunha et al. (2010).
} 
2005). ${ }^{22}$ The dual face of later life complementarity is that early investment is most productive if it is followed up with later life investment.

Complementarity coupled with self-productivity leads to the important concept of dynamic complementarity introduced in Cunha and Heckman $(2007,2009)$. Because investment produces greater stocks of skills $\left(\boldsymbol{I}_{\boldsymbol{t}} \uparrow \Rightarrow \boldsymbol{\theta}_{\boldsymbol{t}+\mathbf{1}} \uparrow\right)$ and because of self-productivity $\left(\boldsymbol{\theta}_{\boldsymbol{t}+\mathbf{1}} \uparrow \Rightarrow \boldsymbol{\theta}_{\boldsymbol{t}+\boldsymbol{s}} \uparrow, s \geq 1\right)$ it follows that:

$$
\frac{\partial^{2} \boldsymbol{\theta}_{\boldsymbol{t}+\boldsymbol{s}+\mathbf{1}}}{\partial \boldsymbol{I}_{\boldsymbol{t}} \partial \boldsymbol{I}_{\boldsymbol{t}+\boldsymbol{s}}^{\prime}}>0, \quad s \geq 1
$$

Investments in period $t+s$ and investments in any previous period $t$ are always complements as long as $\boldsymbol{\theta}_{t+s}$ and $\boldsymbol{I}_{t+s}$ are complements, irrespective of whether $\boldsymbol{I}_{t}$ and $\boldsymbol{\theta}_{t}$ are complements or substitutes in some earlier period $t .{ }^{23}$ Early investment enhances later life investment, even if early investment substitutes for early stage skills.

These properties of the technology of skill formation show why investment in disadvantaged (low- $\boldsymbol{\theta}_{\boldsymbol{t}}$ ) adolescents can be both socially fair and economically efficient, whereas later-stage investments in disadvantaged adults, although fair, may be economically inefficient. Building the skill base of disadvantaged young children makes them more productive at later ages. Dynamic complementarity also shows why investments in disadvantaged adolescents and young adults who lack a suitable skill base are often less effective.

These properties of the technology explain, in part, why more advantaged children were the first to respond in terms of college attendance to the rising returns to education (see Cunha et al., 2006). They had the necessary skill base to benefit from more advanced levels of schooling as the returns increased. These properties also explain the failure of tuition subsidy policies in promoting the educational participation of disadvantaged adolescents (see Heckman, 2008). They lack the necessary skills to go on to college. Dynamic complementarity also suggests that limited access to parenting resources at early ages can have lasting lifetime consequences that

\footnotetext{
${ }^{22}$ It is not inconsistent with the notion that later life investments for persons with high levels of $\boldsymbol{\theta}$ may have substantial effects and be cost-effective. It is also consistent with the notion that later life information and guidance can enhance the effectiveness of a given stock of skills (See Bettinger et al., 2012).

${ }^{23}$ For a proof see Heckman and Mosso (2014).
} 
are difficult to remediate at later ages.

Parental skills also play a disequalizing role as they enhance the productivity of investments $\left(\frac{\partial^{2} \boldsymbol{\theta}_{\boldsymbol{t}+1}}{\partial \boldsymbol{\theta}_{\boldsymbol{P}, \boldsymbol{t}} \partial \boldsymbol{I}_{\boldsymbol{t}}^{\prime}}>0\right)$. There is evidence that more educated parents, by their more frequent engagement with their children, increase the formative value of investments such as sports or cultural activities (Lareau, 2011). The evidence reported by Dickson et al. in this issue shows that boosting the education of the least educated persons who become parents has a beneficial effect on child scores on achievement tests.

Public investments are usually thought to promote equality. Whether or not they do so depends on the patterns of substitutability with private investments and parental skills. If more skilled parents are able to increase the productivity of public investments as they are estimated to do with private ones, or if public investments crowd out private investments relatively more among disadvantaged families, then public investments will also play a role towards disequalization. ${ }^{24}$

\subsection{Other Ingredients}

In addition to the functions linking outcomes to skills and the technology of skill formation, a fully specified model of family influence considers family preferences for child outcomes. Parents have different beliefs about "proper" child rearing, and can act altruistically or paternalistically (see, e.g., Baumrind, 1968, Bisin and Verdier, 2001, and Doepke and Zilibotti, 2012). ${ }^{25}$ Parents may also have different preferences, and different patterns of labor market specialization, depending on child gender (Lundberg, 2005). A fully specified model also includes family resources broadly defined, such as parental and child interactions with financial markets and external institutions. This includes restrictions (if any) on transfers across generations, restrictions on transfers within generations (parental lifetime liquidity constraints),

\footnotetext{
${ }^{24}$ This is an argument against the universal provision of policies to promote the equality of outcomes. The evidence supporting the complementarity hypothesis is mixed. See Pop-Eleches and Urquiola (2013) and Gelber and Isen (2013).

${ }^{25}$ Altruistic parents care about the utility of their child and therefore evaluate their child's actions using the child's utility function. Paternalistic parents, on the other hand, potentially disapprove of their child's actions, as these are evaluated through the lenses of the parents' utility function. The literature has not yet reached a consensus on the specification of parental preferences, and evidence on the precise form of parental preferences for child outcomes is scant.
} 
and the public provision of investments in children. The paper by Carneiro and Ginja (this issue) suggests that transitory shocks in family income are smoothed out and have little effect on child outcomes. This is consistent with the absence of short-term credit constraints.

Credit constraints are traditional components of economic analysis. Less traditional, but central to the recent literature are other constraints on parents: (a) information on parenting practices and parental guidance (Cunha et al., 2013); (b) genes; and (c) the structure of households, including assortative matching patterns.

\subsection{The Empirical Challenge}

There is a substantial empirical challenge facing the analyst of family influence on child outcomes. Influences at different stages of the life cycle build on each other. Evidence of early family influence on adult outcomes is consistent with strong initial effects that may be attenuated at subsequent stages of the life cycle or weak initial effects that are amplified at later stages of the life cycle. The empirical challenge is to sort out the relative importance of the different causal influences on adult outcomes and stages of the life cycle where they are most influential.

\subsection{Recent Developments}

Some of the leading models in the recent literature make explicit assumptions about parental preferences and generate multiple-generation frameworks. Heckman and Mosso (2014) survey the recent literature. Most studies assume parental altruism, but a few are explicitly paternalistic. They all feature investment in goods. Only recently has parental time been analyzed as an explicit input to child quality. The studies by Carneiro and Ginja, Del Bono et al. and Del Boca et al. in this Symposium explicitly analyze time investments.

Most models analyze how child investment depends on parental skills. Surprisingly, however, some of the recent models omit parental skills (such as parental education) as arguments in the technology of skill formation despite the evidence in a large literature that parental skills (apart from explicit parental investments) are 
important factors in producing child skills. ${ }^{26}$ The paper by Dickson et al. in this issue confirms this point, as do earlier papers by Carneiro et al. (2013), Cunha et al. (2010) and Cunha and Heckman (2008). Until recently, most studies considered the self-productivity of skills. However, some recent papers ignore this feature, despite the empirical evidence that supports it.

Most analyses assume that parents know the technology of skill formation, as well as the skills of their children, in making investment decisions. Cunha et al. (2013) is an important exception. The recent literature also ignores intergenerational transfers. Some papers consider extreme credit constraints that do not permit any borrowing (or lending), even within a lifetime of a generation, much less with regard to inter-generational transfers. ${ }^{27}$ Virtually the entire literature focuses on single-child models, exogenous fertility, and exogenous mating decisions. Most models focus on the behavior of only one parent, typically the mother, and the characteristics of the other parent are essentially treated as irrelevant. ${ }^{28}$

These models do not capture some essential features of the process of child development. First, with the exception of Cunha and Heckman (2008) and Cunha et al. (2010), human capital is treated as a scalar. This is inconsistent with the basic facts presented in Section 1. It is a practice inherited from the early literature of Becker and Tomes (1979, 1986), and Solon (2004). Skills are multidimensional. Borghans et al. (2008), Almlund et al. (2011), and Heckman and Kautz (2012, 2014) present evidence showing that a single skill, such as cognitive ability or IQ, is insufficient to summarize the determinants of life achievements.

Second, in some recent models, investments are also treated as scalars. In truth, parents and schools have access to and use multiple forms of investment, and the nature of the investments changes over the life cycle of the child. The most relevant omissions in the early models of child development are time investments. Quality parenting is a time-intensive process. The recent literature shows that parental time is a prime factor influencing child skill formation (Bernal, 2008; Bernal and Keane, 2010, 2011; Del Boca et al., 2014; Gayle et al., 2014; Lee and Seshadri, 2014). Papers

\footnotetext{
${ }^{26}$ See, e.g., Cunha and Heckman (2008) and Cunha et al. (2010).

${ }^{27}$ See Del Boca et al. (2014) and their paper in this issue.

${ }^{28}$ Gayle et al. (2014) is a notable exception.
} 
by Del Bono et al., Del Boca et al. and Carneiro and Ginja in this issue explicitly introduce parental time as determinants of child development. Del Bono et al. and Del Boca et al. use very precise measures of parenting time and child investment that improve on previously used measures of parental time invested in children: the complement of time not spent working. Families differ in their productivity and availability of time and face different opportunity costs. Time investments may complement or substitute for goods investments. In addition, spending time with children allows parents to more accurately assess the capacities of their children and to make more precisely targeted investment decisions. Parent-child/child-mentor interactions operate in real time and parents/mentors actively engage the child to stimulate learning.

Third, families usually have more than one child. Parents make decisions on how to allocate investments across different siblings, compensating for or reinforcing initial differences among them (Behrman et al., 1982). Parental preferences might conflict with what is socially optimal (Del Bono et al., 2012). Del Boca et al. (2014) and Gayle et al. (2014) present models with multiple children. Firstborn children receive relatively more early investment and appear to do better as adults (see, e.g., Black et al., 2005a and Hotz and Pantano, 2013). This is consistent with dynamic complementarity.

Fourth, the models in the literature ignore the interaction of parents and children in the process of development. They treat the child as a passive being whose skills are known to the parent. They assume that the parent fully internalizes the child's utility as her own and the child's utility function is that of the parents. Heckman and Mosso (2014) and García and Heckman (2015) discuss mentor-child interactions. Akabayashi (2006), Lizzeri and Siniscalchi (2008), Hotz and Pantano (2013) and Cosconati (2009) are important early contributions.

Fifth, fertility is taken as exogenous. Forward-looking parents might attempt to time their fertility to balance the benefit from the presence of a child with the need and desire to provide a certain amount of monetary and time investments. The motive to avoid credit constraints, for example, may induce a greater delay in fertility for parents with a high preference for child quality. The greater the 
desired level of investment, the costlier it is to hit an early constraint. To avoid this risk, parents may delay fertility until a sufficient level of precautionary assets has been accumulated. This observation is consistent with the fertility decisions of more educated parents (Almlund, 2013). ${ }^{29}$ This consideration suggests caution in taking too literally the models of credit constraints interacting with dynamic complementarity that take fertility as exogenously determined. The parents who hit the constraints may be less farsighted and may have less information. A variety of other attributes might be confounded with any effect of the levels of income or the constraint itself. In the empirical work on the importance of credit constraints, these factors are rarely accounted for.

Finally, a child's development is influenced by the environment outside his family: day care, kindergarten, school, and neighborhood. The effectiveness of policies is determined in part by parental responses to them. Policies that complement rather than substitute for family investments will have greater impacts and lower costs. Heckman and Mosso (2014) summarize the evidence on parental responses to interventions.

\section{Credit Constraints and the Effects of Family Income on Child Development}

The literature is unanimous in establishing that families with higher levels of longrun (or permanent) income on average invest more in their children and have children with greater skills. The paper by Carneiro and Ginja in this Symposium supports this finding. The literature is much less clear in distinguishing the effect of income by source or in distinguishing pure income effects from substitution effects induced by changing wages and prices (including child-care subsidies or educational incentive payments). If some part of family income change results from changes in labor supply, this will have implications for child development (see, e.g., Bernal, 2008; Bernal and Keane, 2010, 2011; Del Boca et al., 2012; Del Boca et al., 2014;

\footnotetext{
${ }^{29}$ Gayle et al. (2014) provide the only paper of which we are aware that analyzes the impact of endogenous fertility choices on child outcomes.
} 
Ermisch and Francesconi, 2013; Gayle et al., 2014 and Del Boca et al. in this issue). Higher levels of parental permanent income are associated with higher levels of parental education, better schools, more capable parents, better peers, more engaged parenting, etc. All of these factors likely affect child development and much of the body of evidence does not discriminate among competing explanations.

Carneiro and Heckman (2003) and Cunha et al. (2006) present evidence that child cognitive and noncognitive skills diverge at early ages across families with different levels of permanent income during childhood. ${ }^{30}$ Levels of permanent income are highly correlated with family background factors such as parental education and maternal ability, which, when statistically controlled for, largely eliminate the gaps across income classes. The literature sometimes interprets this conditioning as reflecting parenting and parental investments, but it could arise from any or all of the correlates of permanent income associated with parental preferences and skills. This poses a major empirical challenge. The evidence by Carneiro and Ginja in this special issue shows that permanent income effects on family child input decisions are especially important for families where the mother has less education.

\subsection{Effects of Borrowing Constraints}

The literature also analyzes the effect of borrowing constraints on child outcomes. It considers whether there are Pareto-optimal interventions in borrowing markets that can improve the welfare of children and parents, given initial distributions of income (see, e.g., the survey in Lochner and Monge-Naranjo, 2012). If markets are perfect, altruistic or selfish parents who can write binding contracts with their children will ensure that marginal returns to investments in skills will equal the market opportunity costs of funds. ${ }^{31}$ However, even with perfect lending and borrowing markets, equalizations of marginal returns in investment with opportunity cost of funds does not imply equalization of child outcomes across families. The presence of parental environmental inputs $\boldsymbol{\theta}_{\boldsymbol{P}}$ in the technology of skill formation affects the level of investment in children and hence a child's skills and the welfare of the

\footnotetext{
${ }^{30}$ This evidence is discussed in Heckman and Mosso (2014).

${ }^{31}$ Even in the absence of perfect markets, parents may shape sibling preferences to achieve economic efficiency (see Yi, 2015).
} 
child. Allocations are Pareto-optimal given initial parental conditions. From other perspectives, however, these market-efficient outcomes may be suboptimal because they depend on the "accident of birth." If, for example, parenting is deficient for whatever reason, choice outcomes might be improved by supplementing family resources (apart from income). A whole host of endowments of the child at the college-going age might be enhanced if the parental environment does not provide the information, the mentoring, and the encouragement (summarized in $\boldsymbol{\theta}_{\boldsymbol{P}}$ and $\boldsymbol{I}$ ), and children cannot insure against these aspects of the environment. ${ }^{32}$

The recent literature that considers multiperiod childhoods investigates the role of the timing of the receipt of income as it interacts with restrictions on credit markets and dynamic complementarity. We briefly review the evidence from these strands of the literature.

\subsection{Lessons from the Literature on Family Income and Credit Constraints}

The literature on credit constraints and family income shows that higher levels of parental resources, broadly defined, promote child outcomes. However, a clear separation of parental resources into pure income flows, parental environmental variables, and parental investment has not yet been done. The paper by Carneiro and Ginja shows that family input decisions are not much affected by permanent or transitory fluctuations in the income of educated mothers, but permanent fluctuations in income have a weak effect on input choices for families with less educated mothers. This body of evidence, taken together with the simulations reported by Del Boca et al. in this issue, suggest that it is premature to advocate income transfer policies as effective means for promoting child development.

The literature establishes the first-order importance of child ability for attending college, irrespective of family income levels. More advantaged families with less able children send their children to college at greater rates than less advantaged families, but the literature does not establish the existence of substantial market

\footnotetext{
${ }^{32}$ Aiyagari et al. (2002) present an analysis of full insurances against the accident of birth.
} 
imperfections or any basis for intervention in credit markets. ${ }^{33}$ The observed empirical regularity may result from the exercise of parental preferences. Recent work shows that the returns to college for less able children are low, if not negative. ${ }^{34}$

The literature that conducts more formal econometric analyses of the importance of credit market restrictions on educational attainment finds mixed evidence for them. ${ }^{35}$ Caucutt and Lochner (2012) calibrate that a substantial fraction of the population is constrained due to the interaction of dynamic complementarity, the receipt of income, and the imperfection of lending markets. Constrained families are concentrated among the highly educated who face more rapid growth of income across the life cycle, and not among the less educated and poorer families who face flatter wage profiles. ${ }^{36}$ Further research is required before definitive policy conclusions can be drawn on the empirical importance of the timing of receipt of income over the life cycle for child outcomes.

\subsection{Structural Estimates of Behavioral Responses to Public Policies}

Most studies of the role of income transfer programs do not investigate the interactions of public policy interventions and family investments. To do so, some authors have estimated fully specified structural models and use them to study the effect of various types of policy experiments. Del Boca et al. (2014) and the Del Boca et al. sequel in this Symposium are excellent examples.

Few clean conclusions emerge from this literature, and most of these are obvious. The authors of these studies estimate different models under different assumptions about financing constraints. Four main facts emerge from the literature. First, subsidies to parental investments are more cost-effective in improving adult outcomes of children such as schooling attainment or earnings, when provided in the early stages of life (Caucutt and Lochner, 2012; Cunha, 2007; Cunha and Heckman,

\footnotetext{
${ }^{33}$ There is no comparable body of evidence for less-developed countries where credit constraints are likely to be important.

${ }^{34}$ See Heckman et al. (2015a).

${ }^{35}$ See the discussion in Heckman and Mosso (2014) who extensively review the structural literature.

${ }^{36}$ Recent work by Navarro (2011) and Hai and Heckman (2015) is consistent with this interpretation of the evidence.
} 
2007). Second, financial investment subsidies have stronger effects for families who are already engaging in complementary investments. Targeted public investments and targeted transfers restricted to child-related goods that guarantee minimum investment amounts to every child increase the level of investments received by the children of the least-active parents (Caucutt and Lochner, 2012; Del Boca et al., 2014 and in this issue). Lee and Seshadri (2014) provide evidence on the importance of targeted education subsidies for increasing the educational expenditures of poor families. Third, time-allocation decisions are affected by transfers. Del Boca et al. in this Symposium and Del Boca et al. (2014) show that unrestricted transfers increase the time parents spend with their children through a wealth effect. ${ }^{37}$ The increase in child quality is minimal. However, Lee and Seshadri (2014) show that such transfers can be especially effective for parents without college education. In their model, public transfers negatively affect time spent with children for college-educated parents. Fourth, targeted conditional transfers (targeted on a child's ability improvements) are more cost-effective than pure income transfers to achieve any child outcome (see Caucutt and Lochner, 2012, Cunha, 2007, and Del Boca et al. in this Symposium).

\section{Interpreting the Intervention Literature}

The models developed in the recent literature in the economics of the family can be used to interpret the intervention literature (see Cunha and Heckman, 2009). Heckman and Kautz (2014) and Kautz et al. (2014) summarize the empirical evidence from a variety of interventions targeting disadvantaged children that range in their target populations from infants to adults. They analyze programs that have been well-studied (usually by randomized trials), have long-term follow-ups, and have been widely advocated. Comparisons among programs are problematic as the various programs differ in the baseline characteristics for the targeted population, in the measurements available to evaluate their effects, and in the packages of interventions offered.

\footnotetext{
${ }^{37}$ Carneiro and Ginja report similar findings.
} 
Heckman and Mosso (2014) summarize the estimated effects for the most important interventions. Three striking patterns emerge. First, many early childhood interventions have longer follow-ups (10 or 20 years) than do adolescent interventions. Second, evaluations of early childhood programs tend to measure cognitive and noncognitive skills in addition to a variety of later-life outcomes. Many evaluations of programs for adolescents focus solely on labor market outcomes. Examination of the curriculum of these programs is necessary to understand their primary program focus (e.g. cognitive or noncognitive stimulation). Third, the selection of children into early interventions often depends on parental choices, whereas adolescent participants decide themselves whether to opt in.

\subsection{The Main Findings of the Literature on Skill En- hancement Programs}

Elango et al. (2015) and Heckman and Kautz (2014) summarize the literature. Three main findings emerge. First, only very early interventions (before age 3) improve IQ in lasting ways consistent with the evidence that early childhood is a critical period for cognitive development. Second, most programs targeting the cognitive skills of disadvantaged adolescents are less effective than early intervention programs. This evidence is broadly consistent with dynamic complementarity. Most of the successful programs are a consequence of the direct effect of incentives put in place in these programs (versions of incapacitation effects), but they fail to have lasting effects. Third, the most promising adolescent interventions feature mentoring and scaffolding. They often integrate work with traditional education and attenuate the rigid separation between school and work that characterizes the American high school. Mentoring involves teaching valuable character (noncognitive) skills (showing up for work, cooperating with others, and persevering on tasks). The effectiveness of mentoring programs is consistent with the evidence on the importance of attachment, parenting, and interaction that is discussed in Heckman and Mosso (2014). Some form of mentoring is present in all successful intervention programs at all stages of childhood. 


\subsection{The Mechanisms Producing the Treatment Effects}

The literature on program evaluation usually focuses on estimating treatment effects and not on the mechanisms producing the treatment effects. The model of skill formation presented in Section 2 facilitates understanding of the mechanisms producing treatment effects by distinguishing the effect of interventions on the vector of skills $\boldsymbol{\theta}_{\boldsymbol{t}}$ (equation (2)) from the effects the skills themselves have on outcomes. It facilitates unification of the family influence literature with the literature on treatment effects.

Heckman et al. (2013) use a factor approach to study a major intervention with a long-term (age 40) follow-up of the Perry Preschool Program. ${ }^{38,39}$ They decompose the experimentally determined treatment effects for adult outcomes into components due to treatment-induced changes in cognitive and noncognitive capacities. They show how the effects of the program primarily operate through the enhancement of noncognitive skills. The program boosted adult health, education, and wages and reduced crime and social isolation for males and females.

The core ingredients of the Perry program are similar to those of the ABC program (see Kuperman Rothkopf and Cheng, 2015). Both promote cognitive and noncognitive skills through scaffolding the child. A long-term evaluation of the ABC program shows striking effects of these interventions on adult health and other child outcomes (see Campbell et al., 2014). The paper by Conti et al. in this issue applies the approach of Heckman et al. (2013) to understand the sources of the treatment effects for health. The program boosted the cognitive and noncognitive skills of participants, which led to healthier lifestyle choices. The main vehicle for improvement is the boost in noncognitive skills. This emerging body of research demonstrates the value of the skill formation approach for interpreting and guiding the analysis of interventions.

\footnotetext{
${ }^{38}$ The program provided disadvantaged three- and four-year-old children the social and emotional stimulation available to most children from more advantaged families (see Kuperman Rothkopf and Cheng, 2015).

${ }^{39}$ It has a rate of return of $7-10 \%$ per annum for boys and girls, analyzed separately (Heckman et al., 2010a,b).
} 


\section{Contributions of the Symposium to the Lit- erature}

The importance of parental time in determining child outcomes has long been recognized by economists, developmental psychologists and epidemiologists (Becker, 1965; Fleisher, 1977; Hill and Stafford, 1974; Leibowitz, 1974; Schaefer and Bayley, 1963). Yet, it is surprising that our knowledge about the effect of maternal and paternal time on child achievements is so limited. Much of the existing recent evidence instead is based on maternal employment or hours worked, which is taken as a proxy for the time that the mother does not spend in child care activities (Baum II, 2003; Baydar and Brooks-Gunn, 1991; Belsky and Eggebeen, 1991; Brooks-Gunn et al., 2002; Ermisch and Francesconi, 2013; Harvey, 1999; Hill et al., 2005; James-Burdumy, 2005; Ruhm, 2004; Waldfogel et al., 2002).

As noted in Del Boca et al. (2014), Del Bono et al. in this Symposium, and Gayle et al. (2014), not all the time mothers do not spend working is actually allocated to their children. Moreover, evidence on maternal employment says very little about the productivity of the time that mothers devote to children. Some (investment) activities are likely to be more productive than others in generating social, human and health capital that, in turn, affects later child outcomes. Such activities may only be weakly correlated with employment decisions and occupation.

The first three of the Symposium papers address this issue, although each of them has different objectives and uses different datasets. The paper by Del Bono, Francesconi, Kelly, and Sacker uses data from the UK Millennium Cohort Study (MCS) to estimate the effect of maternal time inputs on early child development. It distinguishes the time mothers spend in "educational" activities for their children from the time they devote to "recreational" activities. This is an improvement over many of the existing studies that use the Home Observation Measurement of the Environment (HOME), a score which is a scalar index obtained by adding up responses to a battery of questions about the home environment (Aughinbaugh and Gittleman, 2003; Brooks-Gunn et al., 1996; Todd and Wolpin, 2007). It also goes beyond other studies that analyse time use data, which despite the richness of their 
child input measures are generally based on small samples (e.g., Del Boca et al., 2014 and in this issue; Fiorini and Keane, 2014).

Consistent with the recent literature, Del Bono et al. show that there is a strong positive relationship between early maternal time inputs and early child cognitive and emotional skill development. Consistent with the literature on dynamic complementarity, early investments are more productive than later investments. Another reason for this outcome is that parents appear to respond to past outcomes by adjusting their subsequent resource allocation decisions. Once young children are set on a learning path, the skills they acquire at one stage persist into the future and augment the skills attained at later stages.

The second paper by Carneiro and Ginja uses time inputs (an index of time use) as well as other inputs (such as the HOME score and an index of consumption and emotional support). But it has a different goal. It measures the reaction of parental investments in children in time and goods to permanent and transitory income shocks. To construct these measures they use panel data on family income and measures of investments in children from the Children of the National Longitudinal Survey of Youth (CNLSY). Looking at income shocks allows them to consider the exposure to poverty during childhood, which is considered to be an important constraint for child development (Carneiro and Heckman, 2002; Dahl and Lochner, 2012; Duncan and Brooks-Gunn, 1997). It contributes to the literature on credit constraints and child development reviewed above. However, their estimated effects of permanent income shocks on child development are weak, except for families with the least educated mothers (which tend to be lone parents). Even for the disadvantaged mothers, there are no estimated effects of transitory income components on child development.

Investments in children react to permanent fluctuations in family income, in the sense that a negative shock is accompanied by a reduction in the time invested in children. This effect is statistically significant only in households in which the mother has low level of educational attainment. Investments in children do not react to transitory income shocks, especially when children are age 8 or less. The weak size of the permanent income responses suggests that income fluctuations may explain 
only a small component of the adolescent and adult outcomes among individuals who are otherwise equal.

The third paper in this Symposium by Del Boca, Flinn, and Wiswall builds on a previous study by the same authors (Del Boca et al., 2014) that develops a rich model that incorporates time and goods inputs into the production process including parental time in "active" and "passive" child care. It also develops explicit models of parental altruism. The model is estimated using data from the Panel Study of Income Dynamics and its first two Child Development Supplements, and the results used to examine the impact of three broad classes of transfer policies on child development (see also Cunha and Heckman, 2007, Cunha, 2007 and Caucutt and Lochner, 2012 for a related set of policy analyses). The policies they consider are: an unrestricted transfer of income (in which households receive a lump sum transfer with no restrictions on its use), a restricted (or in-kind) transfer of child goods which provide children with better environments outside of the home, and a conditional cash transfer given to households only after the child's measured development satisfies some specific performance criteria.

Conditional cash transfer programmes are considerably more cost effective than restricted and unrestricted transfer programmes. When the transfer is made only after the child's measured development satisfies some performance criteria, some households, that would not qualify otherwise, will efficiently adjust their behaviour (in the sense that they modify their use of inputs) to satisfy the performance criterion specified by the policy and earn the reward. This reward is likely to have an even stronger impact in the long run.

Another aspect of intergenerational links that has attracted considerable research is parental education. This is featured in the very early models (see Leibowitz, 1974) and in the recent models (Cunha and Heckman, 2008; Cunha et al., 2010; Gayle et al., 2014). Parents with higher levels of income and schooling have children who also have higher levels of education, a well established fact. Using data from the Avon Longitudinal Study of Parents and Children (ALSPAC) - a rich cohort dataset of children born in the early 1990s in Avon, England - the fourth paper of the Symposium by Dickson, Gregg, and Robinson, examines the causal 
strength of parental education on child test score outcomes using an instrumental variable treatment-effect approach. It exploits an exogenous shift in education levels induced by the 1972 Raising of the School Leaving Age (RoSLA) reform from age 15 to 16 in England and Wales. Building on many related studies that use instrumental variables techniques (e.g., Black et al., 2005b; Carneiro et al., 2013), this work identifies the age at which the intergenerational transmission of education emerges and effects on literacy and numeracy. It supports the evidence from recent structural literature on parental inputs previously surveyed. Increasing parental education has a positive causal effect on children's test scores. This is evident at age 4 and continues to be visible up to the end of compulsory education (at age 16). The effect is concentrated among less educated parents, who presumably were most affected by the 1972 RoSLA reform. The effects are broadly similar for both numeracy and literacy test scores.

The final paper of this Symposium by Conti, Heckman and Pinto contributes to a broader understanding of the multiple benefits of early interventions. It uses the framework of Heckman et al. (2013) and the data reported on Campbell et al. (2014). It shows important effects of interventions on health and the channels through which it is accomplished. Marmot and Wilkinson (2006) emphasize that it is essential to gain insights not only into the biological mechanisms but also into the social determinants of health and this paper contributes to this end. It investigates the impacts on health of two of the most studied early childhood randomized interventions in the United States, i.e., the Perry Preschool Program and the Carolina Abecedarian Intervention. It shows the channels through which the intervention affected adult outcomes. Boosts in non-cognitive skills are especially important. There is much potential for early life interventions to prevent disease and promote health later in life. In particular, early interventions lead to a better adult health and a lower prevalence of later behavioural risk factors. Another key mechanism underpinning this effect is improved access to health care that results from improved employment - a distinctive feature of the U.S. health care system. 


\subsection{Some Implications of the Papers in This Sympo- sium for Policy}

(1) The results in this Symposium stress the relevance of parental time, especially at the early stages of child life, and its key role in shaping outcomes that can affect life chances at much later stages. The importance of parental time has not been emphasized enough in policy circles. Spending time with children is beneficial for them, but most of the recent policy initiatives worldwide have focused attention on maternal work (and not much on paternal work), parental leave and non-maternal child care. The literature has only recently recognized the dual role of child care and child development (see Blau and Currie, 2006). Early childhood programs provide child care for mothers as well as child development (Elango et al., 2015). Part of the high economic return of the ABC program (Elango et al., 2015) comes from enhanced maternal earnings made possible by the released time afforded parents by child care.

Campaigns that provide information to pregnant women or new mothers on the importance of the time they spend with their children and the activities they engage with them from birth to the early school years are cheap, easy to implement and very effective (see Gertler et al., 2014). Information on the benefits of activities and time with children has so far been accessed by better educated or richer parents. Information campaigns that target disadvantaged families are promising approaches for promoting the well-being of their children.

(2) The evidence by Carneiro and Ginja in this issue suggests that public insurance against income shocks is likely to have, at best, a modest role. We need to look elsewhere to find the sources of gaps in parental investment across families sorted by socioeconomic status. Untargeted income transfer programs are unlikely to have a strong impact on child development (see Del Boca et al. in this issue).

(3) Conditional cash transfer programmes, which transfer income to households only if children reach pre-specified outcome criteria (e.g., a given level of cog- 
nitive or non-cognitive skills) may have a role to play. There is little positive evidence on the effectiveness of parental incentive programs for promoting child development (but see Fryer et al., 2015 and the references therein). The problem with conditional cash transfer programmes is the design of the incentive system, which includes the choice of the reward size, the performance targets, and the agents who should receive the rewards. But possibly, with the appropriate specification of criteria, programmes can limit (if not totally avoid) issues of input underprovision to children (i.e., moral hazard) and strategic manipulation of the eligibility rules into the programmes (i.e., adverse selection).

(4) When dealing with child investment it is also essential to take a long-term view. In this context, for example, educational policies can be extremely effective. The evidence of a positive causal impact on the educational attainment of the next generation from increasing the schooling of individuals who wish to leave school at the first opportunity is especially important because this group of individuals is most at risk of failing to achieve their own potential. A similar risk applies to the children that they go on to have. Other evidence (see the summary in Elango et al., 2015 and Heckman and Mosso, 2014) suggests that targeting the most disadvantaged children with high-quality programs can be an effective strategy.

(5) Another example of long-term view is given by early childhood interventions, such as the Perry Preschool Program and the Abecedarian Intervention in the United States. These are programmes that target disadvantaged children providing early supplements to parenting. Disadvantage is not just a matter of low family income. Simple income transfers are unlikely to be effective. Disadvantage encompasses parenting, attachment, and scaffolding (Elango et al., 2015; Heckman and Mosso, 2014). The extensive economic, psychological, behavioural, and health benefits of the $\mathrm{ABC}$ and Perry programmes warrant their full consideration in discussions of ways to control the soaring costs of the health care and the education systems in many developed countries, as well as vehicles for reducing crime. Elango et al. (2015) show that early child- 
hood programs are most effective for children from the most disadvantaged environments.

\subsection{The Way Forward}

The papers presented here advance the field, yet they have limitations that future research should address. Following a well-established tradition in the literature, many papers in this Symposium measure child outcomes using achievement test scores. This practice ignores the non-cognitive skills that have been shown to be important in predicting life outcomes.

In addition, these papers ignore a crucial problem addressed in Cunha et al. (2010) and Cunha and Heckman (2008): any monotonically increasing transformation of a test score is still a valid test score. Different transformations affect the inference from models that use one particular transformation as an outcome. Valueadded models are particularly sensitive to this point since there is little meaning that can be attached to differences in ordinal variables. Cunha et al. (2010) propose and implement measures of skill that are anchored in interpretable outcomes (schooling attained or income). They show that use of different anchors critically affects the inference from these models.

Some of the models estimated in this issue are linear in inputs. Yet nonlinearity is an important feature of the technology of skill formation (see Heckman and Mosso, 2014). Linear models abstract from the complementarities that are central to the recent literature.

Many of the papers in this Symposium are largely silent about possibilities of borrowing and lending (Carneiro and Ginja is an important exception). Some assume no possibilities (Del Boca et al.) and others implicitly assume parental access to credit markets but are silent on specifics. Alternative specifications of credit market possibilities affect inferences about the importance of family influence (see, e.g., Navarro, 2011).

Finally, many of the papers in this Symposium are silent about the mechanisms producing their estimated effects. A deeper understanding of these mechanisms facilitates comparisons across studies and the formulation of informed public policy. 


\section{References}

Aiyagari, S. R., J. Greenwood, and A. Seshadri (2002, February). Efficient investment in children. Journal of Economic Theory 102(2), 290-321.

Akabayashi, H. (2006). An equilibrium model of child maltreatment. Journal of Economic Dynamics and Control 30(6), 993-1025.

Alan, S. and S. Ertac (2014, July). Patience, self-control and the demand for commitment: Evidence from a large-scale field experiment. Journal of Economic Behavior \& Organization 115, 111-122.

Almlund, M. (2013). Essays on Credit Constraints, Education, and the Family. Ph. D. thesis, University of Chicago, Department of Economics.

Almlund, M., A. Duckworth, J. J. Heckman, and T. Kautz (2011). Personality psychology and economics. In E. A. Hanushek, S. Machin, and L. Wößmann (Eds.), Handbook of the Economics of Education, Volume 4, pp. 1-181. Amsterdam: Elsevier.

Almond, D. and J. Currie (2011). Human capital development before age five. In O. C. Ashenfelter and D. Card (Eds.), Handbook of Labor Economics, Volume 4B, Chapter 15, pp. 1315-1486. North Holland: Elsevier.

Aughinbaugh, A. and M. Gittleman (2003). Does money matter? A comparison of the effect of income on child development in the united states and great britain. Journal of Human Resources 38(2), 416-440.

Barker, D. J. P. (1990, November). The fetal and infant origins of adult disease. London: British Medical Journal 301(6761), 1111.

Baum II, C. L. (2003). Does early maternal employment harm child development? An analysis of the potential benefits of leave taking. Journal of Labor Economics 21(2), 409-448.

Baumrind, D. (1968). Authoritarian vs. authoritative parental control. Adolescence 3(11), 255-272. 
Baydar, N. and J. Brooks-Gunn (1991, November). Effects of maternal employment and child-care arrangements on preschoolers' cognitive and behavioral outcomes: Evidence from the children of the national longitudinal survey of youth. Developmental Psychology 27(6), 932-945.

Becker, G. S. (1965). A theory of the allocation of time. The Economic Journal 75(299), 493-517.

Becker, G. S. and C. B. Mulligan (1997, August). The endogenous determination of time preference. Quarterly Journal of Economics 112(3), 729-758.

Becker, G. S., K. M. Murphy, and J. L. Spenkuch (2012). The manipulation of children's preferences, old age support, and investment in children's human capital. Unpublished manuscript, University of Chicago, Department of Economics.

Becker, G. S. and N. Tomes (1979, December). An equilibrium theory of the distribution of income and intergenerational mobility. Journal of Political Economy $87(6), 1153-1189$.

Becker, G. S. and N. Tomes (1986, July). Human capital and the rise and fall of families. Journal of Labor Economics 4(3, Part 2), S1-S39.

Behrman, J. R., R. A. Pollak, and P. J. Taubman (1982). Parental preferences and provision of progeny. J. Polit. Econ. 90(1), 52-73.

Belsky, J. and D. Eggebeen (1991, November). Early and extensive maternal employment and young children's socioemotional development: Children of the national longitudinal survey of youth. Journal of Marriage and the Family 53(4), 1083-1098.

Ben-Porath, Y. (1967, August). The production of human capital and the life cycle of earnings. Journal of Political Economy 75 (4, Part 1), 352-365.

Bernal, R. (2008). The effect of maternal employment and child care on children's cognitive development. International Economic Review 49(4), 1173-1209. 
Bernal, R. and M. P. Keane (2010). Quasi-structural estimation of a model of childcare choices and child cognitive ability production. Journal of Econometrics $156(1), 164-189$.

Bernal, R. and M. P. Keane (2011). Child care choices and children's cognitive achievement: The case of single mothers. Journal of Labor Economics 29(3), $459-512$.

Bettinger, E. P., B. T. Long, P. Oreopoulos, and L. Sanbonmatsu (2012). The role of application assistance and information in college decisions: Results from the H\&R Block FAFSA experiment. Quarterly Journal of Economics 127(3), $1205-1242$.

Bisin, A. and T. Verdier (2001, April). The economics of cultural transmission and the dynamics of preferences. Journal of Economic Theory 97(2), 298-319.

Black, S. E., P. J. Devereux, and K. G. Salvanes (2005a, May). The More the Merrier? The Effect of Family Size and Birth Order on Children's Education. The Quarterly Journal of Economics 120(2), 669-700.

Black, S. E., P. J. Devereux, and K. G. Salvanes (2005b, March). Why the apple doesn't fall far: Understanding intergenerational transmission of human capital. American Economic Review 95(1), 437-449.

Blau, D. and J. Currie (2006). Preschool, daycare, and afterschool care: Who's minding the kids? In E. A. Hanushek and F. Welch (Eds.), Handbook of the Economics of Education, Volume 2 of Handbooks in Economics, Chapter 20, pp. 1163-1278. Amsterdam: Elsevier.

Bloom, B. S. (1964). Stability and Change in Human Characteristics. New York: Wiley.

Borghans, L., A. L. Duckworth, J. J. Heckman, and B. ter Weel (2008, Fall). The economics and psychology of personality traits. Journal of Human Resources 43(4), 972-1059. 
Borghans, L., B. H. H. Golsteyn, J. J. Heckman, and J. E. Humphries (2011a). Identification problems in personality psychology. Personality and Individual Differences 51 (3: Special Issue on Personality and Economics), 315-320.

Borghans, L., B. H. H. Golsteyn, J. J. Heckman, and J. E. Humphries (2011b). IQ, achievement, and personality. Unpublished manuscript, University of Maastricht and University of Chicago (revised from the 2009 version).

Bowles, S., H. Gintis, and M. Osborne (2001, December). The determinants of earnings: A behavioral approach. Journal of Economic Literature 39(4), 11371176 .

Brooks-Gunn, J., W.-J. Han, and J. Waldfogel (2002). Maternal employment and child cognitive outcomes in the first three years of life: The nichd study of early child care. Child Development 73(4), 1052-1072.

Brooks-Gunn, J., P. K. Klebanov, and G. J. Duncan (1996). Ethnic differences in children's intelligence test scores: Role of economic deprivation, home environment, and maternal characteristics. Child Development 67(2), 396-408.

Browning, M., L. P. Hansen, and J. J. Heckman (1999, December). Micro data and general equilibrium models. In J. B. Taylor and M. Woodford (Eds.), Handbook of Macroeconomics, Volume 1A, Chapter 8, pp. 543-633. Elsevier.

Cameron, S. V. and J. J. Heckman (2001, June). The dynamics of educational attainment for black, hispanic, and white males. Journal of Political Economy 109(3), 455-499.

Campbell, F. A., G. Conti, J. J. Heckman, S. H. Moon, R. Pinto, and E. P. Pungello (2014). Early childhood investments substantially boost adult health. Science 343(6178), 1478-1485.

Carneiro, P. and J. J. Heckman (2002, October). The evidence on credit constraints in post-secondary schooling. Economic Journal 112(482), 705-734. 
Carneiro, P. and J. J. Heckman (2003). Human capital policy. In J. J. Heckman, A. B. Krueger, and B. M. Friedman (Eds.), Inequality in America: What Role for Human Capital Policies?, pp. 77-239. Cambridge, MA: MIT Press.

Carneiro, P., I. Lopez Garcia, K. G. Salvanes, and E. Tominey (2013). Intergenerational mobility and the timing of parental income. In CES Ifo Conference on Economics of Education, September 6-7, 2013, CES Ifo Area Conferences. CES Ifo.

Carneiro, P., C. Meghir, and M. Parey (2013, January). Maternal education, home environments, and the development of children and adolescents. Journal of the European Economic Association 11, 123160.

Carrell, S. E. and B. Sacerdote (2013). Late interventions matter too: The case of college coaching New Hampshire. Working Paper 19031, National Bureau of Economic Research.

Caucutt, E. M. and L. J. Lochner (2012). Early and late human capital investments, borrowing constraints, and the family. Working Paper 18493, National Bureau of Economic Research.

Cole, S. W., G. Conti, J. M. G. Arevalo, A. M. Ruggiero, J. J. Heckman, and S. J. Suomi (2012). Transcriptional modulation of the developing immune system by early life social adversity. Proceedings of the National Academy of Sciences 109(50), 20578-20583.

Conti, G., J. J. Heckman, and R. Pinto (2015). The long-term health effects of early childhood interventions. Forthcoming, Economic Journal.

Cook, P. J., K. Dodge, G. Farkas, R. G. Fryer, Jr, J. Guryan, J. Ludwig, S. Mayer, H. Pollack, and L. Steinberg (2014, January). The (surprising) efficacy of academic and behavioral intervention with disadvantaged youth: Results from a randomized experiment in Chicago. Working Paper 19862, National Bureau of Economic Research (NBER). 
Cosconati, M. (2009, February). Parenting style and the development of human capital in children. Unpublished manuscript, Department of Economics, University of Pennsylvania.

Cunha, F. (2007). An Essay on Skill Formation. Ph. D. thesis, University of Chicago.

Cunha, F., I. T. Elo, and J. Culhane (2013, June). Eliciting maternal expectations about the technology of cognitive skill formation. Working Paper 19144, National Bureau of Economic Research.

Cunha, F. and J. J. Heckman (2007, May). The technology of skill formation. American Economic Review 97(2), 31-47.

Cunha, F. and J. J. Heckman (2008, Fall). Formulating, identifying and estimating the technology of cognitive and noncognitive skill formation. Journal of Human Resources 43(4), 738-782.

Cunha, F. and J. J. Heckman (2009, April). The economics and psychology of inequality and human development. Journal of the European Economic Association 7(2-3), 320-364.

Cunha, F., J. J. Heckman, L. J. Lochner, and D. V. Masterov (2006). Interpreting the evidence on life cycle skill formation. In E. A. Hanushek and F. Welch (Eds.), Handbook of the Economics of Education, Chapter 12, pp. 697-812. Amsterdam: North-Holland.

Cunha, F., J. J. Heckman, and S. Navarro (2005, April). Separating uncertainty from heterogeneity in life cycle earnings, The 2004 Hicks Lecture. Oxford Economic Papers 57(2), 191-261.

Cunha, F., J. J. Heckman, and S. M. Schennach (2010, May). Estimating the technology of cognitive and noncognitive skill formation. Econometrica 78(3), 883-931. 
Dahl, G. B. and L. Lochner (2012, September). The impact of family income on child achievement: Evidence from the earned income tax credit. American Economic Review 102(5), 1927-56.

Del Boca, D., C. Flinn, and M. Wiswall (2012). Transfers to households with children and child development. Carlo Alberto Notebooks 273, Moncalieri Torino, Italy: Collegio Carlo Alberto.

Del Boca, D., C. J. Flinn, and M. Wiswall (2014). Household choices and child development. Review of Economic Studies 81(1), 137-185.

Del Bono, E., J. Ermisch, and M. Francesconi (2012). Intrafamily Resource Allocations: A Dynamic Structural Model of Birth Weight. Journal of Labor Economics 30(3), 657-706.

Doepke, M. and F. Zilibotti (2012). Parenting with style: Altruism and paternalism in intergenerational preference transmission. Discussion Paper 7108, Institute for the Study of Labor (IZA).

Dohmen, T., A. Falk, D. Huffman, and U. Sunde (2010). Are risk aversion and impatience related to cognitive ability? American Economic Review $100(3)$, $1238-1260$.

Duckworth, K., G. J. Duncan, K. Kokko, A.-L. Lyyra, M. Metzger, and S. Simonton (2012). The relative importance of adolescent skills and behaviors for adult earnings: A cross-national study. Department of Quantitative Social Science Working Paper 12-03, University of London.

Duncan, G. J. and J. Brooks-Gunn (1997). Consequences of Growing Up Poor. New York: Russell Sage Foundation.

Eisenhauer, P., J. Heckman, and S. Mosso (2015). Estimation of dynamic discrete choice models by maximum likelihood and the simulated method of moments. Forthcoming, International Economic Review.

Elango, S., J. L. García, J. J. Heckman, A. Hojman, D. Ermini, M. J. Rados, J. Shea, and J. C. Torcasso (2015). The internal rate of return and the benefit-cost 
ratio of the Carolina Abecedarian Project. University of Chicago, Department of Economics.

Elango, S., A. Hojman, J. L. García, and J. J. Heckman (2015). Early childhood education. Forthcoming, in Moffitt, Robert (ed.), Means-tested Transfer Programs in the United States II. Chicago: University of Chicago Press, 2016.

Ermisch, J. and M. Francesconi (2013). The effect of parental employment on child schooling. Journal of Applied Econometrics 28(5), 796-822.

Fernald, A., V. A. Marchman, and A. Weisler (2013). SES differences in language processing skill and vocabulary are evident at 18 months. Developmental Science $16(2), 234-248$.

Fiorini, M. and M. P. Keane (2014). How the Allocation of Children's Time Affects Cognitive and Non-Cognitive Development. Journal of Labor Economics 4(32), $787-836$.

Fleisher, B. M. (1977). Mothers home time and the production of child quality. Demography 14(2), 197-212.

Fryer, Jr., R. G., S. D. Levitt, and J. A. List (2015, August). Parental incentives and early childhood achievement: A field experiment in chicago heights. Working Paper 21477, National Bureau of Economic Research (NBER).

García, J. L. (2014). Ability, character, and social mobility. University of Chicago, Department of Economics.

García, J. L. and J. J. Heckman (2015). Parenting, skills, and social mobility. University of Chicago, Department of Economics.

Gayle, G.-L., L. Golan, and M. A. Soytas (2014). What accounts for the racial gap in time allocation and intergenerational transmission of human capital. 2014 Meeting Papers 83.

Gelber, A. M. and A. Isen (2013). Children's schooling and parents' behavior: Evidence from the head start impact study. Journal of Public Economics 101, $25-38$. 
Gertler, P., J. J. Heckman, R. Pinto, A. Zanolini, C. Vermeersch, S. Walker, S. Chang, and S. M. Grantham-McGregor (2014). Labor market returns to an early childhood stimulation intervention in Jamaica. Science 344(6187), 9981001.

Gluckman, P. D. and M. Hanson (2005). The Fetal Matrix: Evolution, Development, and Disease. Cambridge, UK: Cambridge University Press.

Gluckman, P. D. and M. A. Hanson (2006). Developmental Origins of Health and Disease. Cambridge, UK: Cambridge University Press.

Hai, R. and J. J. Heckman (2015). A dynamic model of health, education, and wealth with credit constraints and rational addiction. University of Chicago.

Hales, C. N. and D. J. P. Barker (1992). Type 2 (non-insulin-dependent) diabetes mellitus: The thrifty phenotype hypothesis. Diabetologia 35(7), 595-601.

Harris, J. R. (2006). No Two Alike: Human Nature and Human Individuality. New York: W.W. Norton and Company.

Hart, B. and T. R. Risley (1995). Meaningful differences in the everyday experience of young American children. Baltimore, MD: P.H. Brookes.

Harvey, E. (1999). Short-term and long-term effects of early parental employment on children of the national longitudinal survey of youth. Developmental Psychology $35(2), 445-459$.

Heckman, J., J. E. Humphries, and G. Veramendi (2015a). The causal effects of education on earnings and health. Unpublished manuscript, Department of Economics, University of Chicago.

Heckman, J. J. (2008, July). Schools, skills and synapses. Economic Inquiry 46(3), $289-324$

Heckman, J. J., J. E. Humphries, and G. Veramendi (2015b). The non-market benefits of abilities and education. Unpublished manuscript, University of Chicago. 
Heckman, J. J. and T. Kautz (2012, August). Hard evidence on soft skills. Labour Economics 19(4), 451-464. Adam Smith Lecture.

Heckman, J. J. and T. Kautz (2014). Fostering and measuring skills: Interventions that improve character and cognition. In J. J. Heckman, J. E. Humphries, and T. Kautz (Eds.), The Myth of Achievement Tests: The GED and the Role of Character in American Life, Chapter 9, pp. 341-430. Chicago: University of Chicago Press.

Heckman, J. J., R. J. LaLonde, and J. A. Smith (1999). The economics and econometrics of active labor market programs. In O. Ashenfelter and D. Card (Eds.), Handbook of Labor Economics, Volume 3A, Chapter 31, pp. 1865-2097. New York: North-Holland.

Heckman, J. J., S. H. Moon, R. Pinto, P. A. Savelyev, and A. Q. Yavitz (2010a, August). Analyzing social experiments as implemented: A reexamination of the evidence from the HighScope Perry Preschool Program. Quantitative Economics 1(1), 1-46.

Heckman, J. J., S. H. Moon, R. Pinto, P. A. Savelyev, and A. Q. Yavitz (2010b, February). The rate of return to the HighScope Perry Preschool Program. Journal of Public Economics 94(1-2), 114-128.

Heckman, J. J. and S. Mosso (2014). The economics of human development and social mobility. Annual Review of Economics 6(1), 689-733.

Heckman, J. J., R. Pinto, and P. A. Savelyev (2013). Understanding the mechanisms through which an influential early childhood program boosted adult outcomes. American Economic Review 103(6), 2052-2086.

Heckman, J. J. and G. L. Sedlacek (1985, December). Heterogeneity, aggregation, and market wage functions: An empirical model of self-selection in the labor market. Journal of Political Economy 93(6), 1077-1125.

Hill, C. R. and F. P. Stafford (1974). Allocation of time to preschool children and educational opportunity. Journal of Human Resources 9(3), 323-341. 
Hill, J. L., J. Waldfogel, J. Brooks-Gunn, and W. J. Han (2005, November). Maternal employment and child development: A fresh look using newer methods. Developmental Psychology 41(6), 833-850.

Hotz, V. J. and J. Pantano (2013, October). Strategic parenting, birth order and school performance. Working Paper 19542, National Bureau of Economic Research.

Huggett, M., G. Ventura, and A. Yaron (2011). Sources of lifetime inequality. American Economic Review 101(7), 2923-2954.

Jablonka, E. and G. Raz (2009). Transgenerational epigenetic inheritance: Prevalence, mechanisms, and implications for the study of heredity and evolution. The Quarterly Review of Biology 84(2), pp. 131-176.

James-Burdumy, S. (2005). The effect of maternal labor force participation on child development. Journal of Labor Economics 23(1), 177-211.

Kalil, A. (2013). Inequality begins at home: The role of parenting in the diverging destinies of rich and poor children. Unpublished manuscript, University of Chicago, Harris School of Public Policy. Presented at Penn State's 21st annual Symposium on Family Issues "Diverging destinies: Families in an era of increasing inequality," October 2013.

Kautz, T., J. J. Heckman, R. Diris, B. ter Weel, and L. Borghans (2014). Fostering and measuring skills: Improving cognitive and non-cognitive skills to promote lifetime success. Technical report, Organisation of Economic Cooperation of Development.

Keane, M. P. and K. I. Wolpin (1997, June). The career decisions of young men. Journal of Political Economy 105(3), 473-522.

Knudsen, E. I., J. J. Heckman, J. Cameron, and J. P. Shonkoff (2006, July). Economic, neurobiological, and behavioral perspectives on building America's future workforce. Proceedings of the National Academy of Sciences 103(27), 1015510162. 
Kuperman Rothkopf, S. and C. Cheng (2015). Comparison of randomized early childhood interventions as they were implemented: Perry, ABC, CARE, and IHDP. University of Chicago, Department of Economics.

Kuzawa, C. W. and E. A. Quinn (2009). Developmental origins of adult function and health: Evolutionary hypotheses. Annual Review of Anthropology 38, 131-147.

Lareau, A. (2011). Unequal Childhoods: Class, Race, and Family Life (2 ed.). Berkeley, CA: University of California Press.

Lee, S. Y. and A. Seshadri (2014). On the intergenerational transmission of economic status. Unpublished manuscript, University of Wisconsin-Madison, Department of Economics.

Leibowitz, A. (1974, March/April). Home investments in children. Journal of Political Economy 82(2), S111-S131.

Lizzeri, A. and M. Siniscalchi (2008, August). Parental guidance and supervised learning. Quarterly Journal of Economics 123(3), 1161-1195.

Lochner, L. J. and A. Monge-Naranjo (2012). Credit constraints in education. Annual Review of Economics 4, 225-256.

Lundberg, S. (2005). The Division of Labor by New Parents: Does Child Gender Matter. Discussion Paper 1787, IZA.

Marmot, M. G. and R. G. Wilkinson (2006). Social determinants of health (Second ed.). Oxford University Press.

Moffitt, T. E. (2005, July). The New Look of Behavioral Genetics in Developmental Psychopathology: Gene-Environment Interplay in Antisocial Behaviors. Psychological Bulletin 131(4), 533-554.

Moon, S. H. (2014). Multi-dimensional human skill formation with multidimensional parental investment. Unpublished manuscript, University of Chicago, Department of Economics. 
Navarro, S. (2011). Using observed choices to infer agent's information: Reconsidering the importance of borrowing constraints, uncertainty and preferences in college attendance. Working Paper 20118, University of Western Ontario, CIBC Centre for Human Capital and Productivity.

Nisbett, R. E., J. Aronson, C. Blair, W. Dickens, J. Flynn, D. F. Halpern, and E. Turkheimer (2012). Intelligence: New findings and theoretical developments. American Psychologist 67(2), 130-159.

Plomin, R. (1999). Genetics and general cognitive ability. Nature 402, C25-C29.

Pop-Eleches, C. and M. Urquiola (2013). Going to a better school: Effects and behavioral responses. American Economic Review 103(4), 1289-1324.

Rubinstein, Y. and Y. Weiss (2006). Post schooling wage growth: Investment, search and learning. In E. Hanushek and F. Welch (Eds.), Handbook of the Economics of Education, Volume 1 of Handbooks in Economics, Chapter 1, pp. 1-67. Amsterdam: North-Holland.

Ruhm, C. J. (2004). Parental employment and child cognitive development. The Journal of Human Resources 39(1), 155-192.

Rutter, M. (2006). Genes and Behavior: Nature-Nurture Interplay Explained. Oxford, UK: Blackwell Publishers.

Rutter, M. (2010). Deprivation-specific psychological patterns : effects of institutional deprivation, Volume serial no. 295, vol. 75, no. 1, 2010. Boston, Mass.: Wiley-Blackwell.

Schaefer, E. S. and N. Bayley (1963). Maternal behavior, child behavior, and their intercorrelations from infancy through adolescence. Monographs of the Society for Research in Child Development 28(3), 1-127.

Schore, A. N. (1994). Affect Regulation and the Origin of the Self: The Neurobiology of Emotional Development. Psychology Press. 
Solon, G. (2004). A model of intergenerational mobility variation over time and place. In M. Corak (Ed.), Generational income mobility in North America and Europe, Chapter 2, pp. 38-47. Cambridge: Cambridge University Press.

Sroufe, L. A., B. Egeland, E. Carlson, and W. A. Collins (2005). The Development of the Person: The Minnesota Study of Risk and Adaptation from Birth to Adulthood. New York: Guilford Press.

Thompson, R. A. and C. A. Nelson (2001, January). Developmental science and the media: Early brain development. American Psychologist 56(1), 5-15.

Todd, P. E. and K. I. Wolpin (2007, Winter). The production of cognitive achievement in children: Home, school, and racial test score gaps. Journal of Human Capital 1(1), 91-136.

Tucker-Drob, E. M., K. Paige Harden, and E. Turkheimer (2009). Combining nonlinear biometric and psychometric models of cognitive abilities. Behavior Genetics $39(5), 461-471$.

Turkheimer, E., A. Haley, M. Waldron, B. D’Onofrio, and I. I. Gottesman (2003, November). Socioeconomic status modifies heritability of IQ in young children. Psychological Science 14(6), 623-628.

Waldfogel, J., W.-J. Han, and J. Brooks-Gunn (2002). The effects of early maternal employment on child cognitive development. Demography 39(2), 369-392.

Yi, J. (2015). Endogenous altruism: Theory and evidence from Chinese twins. Under revision, Journal of Political Economy. 